\title{
The potential for a fish ladder to mitigate against the loss of marine-estuarine-freshwater connectivity in a subtropical coastal lake
}

\author{
SP Weerts ${ }^{1,2 *}$, CF MacKay $^{3}$ and DP Cyrus ${ }^{1}$ \\ 'Coastal Research Unit of Zululand, Department of Zoology, University of Zululand, Private Bag X1001, KwaDlangezwa 3886, \\ KwaZulu-Natal, South Africa \\ ${ }^{2}$ Present address: Natural Resources and the Environment, CSIR, PO Box 17001, Congella, 4013, South Africa \\ ${ }^{3}$ Oceanographic Research Institute, PO Box 10712, Marine Parade, Durban, 4056, South Africa
}

\begin{abstract}
Increasing water demand in coastal regions has resulted in the construction of weirs and barrages in coastal freshwaters. These form barriers to migrations of estuarine and euryhaline marine fishes and crustaceans. This study assessed the impact of loss of marine-estuarine-freshwater connectivity caused by a weir at the outlet of Lake Mzingazi, a coastal lake on the subtropical east coast of South Africa. Facultative catadromous estuarine and euryhaline marine fishes were most affected by the weir, which blocked their upstream migration. These fishes were absent in the lake and were prevented from accessing potential nursery habitat. Crustaceans were less affected by the outlet weir. Salinity tolerances of most penaeid prawn species occurring in southern African estuaries prevent penetration into freshwater reaches of connected systems. Movements of palaemonid prawns which either spawn in or have larvae dependant on estuarine water, and the marine spawning brachyuran Varuna litterata, were not completely impeded by the weir. These species have larvae and juveniles that can climb over the weir in its present form. Historically, the lake served as an estuarine nursery and its physico-chemistry and habitats still offer viable and valuable habitat to estuarine species. There is therefore great potential value in installing a fish ladder at the lake outlet that can be used by juvenile fishes and crustaceans. Re-establishing marine-estuarine-freshwater connectivity here will reinstate a natural migration route that has been impeded for over 70 years and partially restore the ecosystem to its original state.
\end{abstract}

Keywords: Coastal lake, weir, migration barrier, fish, crustaceans, estuarine, Varuna litterata, fish ladder

\section{INTRODUCTION}

Human population growth and economic development has increased pressure on freshwater resources in many parts of the world. The main response to this has been the construction of dams. These often form impenetrable barriers to free movement of aquatic fauna in rivers, with consequent ecological implications. Impacts on migratory fish species are the most studied. Best documented are cases involving anadromous salmonids which undergo mass migrations from marine waters to spawning grounds in mountain reaches of rivers.

Fish ladders (or fishways) are structures that enable fish to migrate beyond obstructions such as dams. They have been used in northern hemisphere countries for centuries. Their primary application has been in rivers where barriers have blocked adult fish access to higher river reaches favoured for spawning. Cases where fishways have been used to promote upstream migration of juvenile fishes to nursery habitats are less well known, probably as a result of species involved having less economic significance in fisheries. However, the importance of managing natural resources at the level of ecosystem has become increasingly recognised (Skelton, 2000), and maintaining migration routes for fishes that are not necessarily of great

To whom all correspondence should be addressed.

III +27 31 242-2356; fax: +27 31 261-2509;

e-mail: sweerts@csir.co.za

Received 21 May 2013; accepted in revised form 17 December 2013. direct economic importance has been accepted as important for ecological integrity and maintaining biodiversity. The latter is a fundamental element of ecological goods and services (Millennium Ecosystem Assessment, 2005).

Dams in South Africa have severely impacted indigenous freshwater fish populations (Jubb, 1967). Although this has long been recognised, fish ladders are a relatively new development in the country (Davies and Day, 1998). The fact that fish conservation efforts initially focussed on alien sport angling species (Coke, 1988) has been largely responsible for this. Over recent decades considerable effort and expense has been invested in projects aimed at restoring natural migration routes of freshwater fishes (DWAF, 1991; 1995). Most of this effort has been invested in inland regions.

Increasingly, however, municipal, industrial, mining and farming sectors in coastal regions are resorting to coastal freshwaters to meet their water requirements. On the east coast of South Africa, coastal lakes are increasingly targeted as sources of freshwater for human use. In many cases this results in the construction of weirs at their outlets to increase yields or prevent salt water penetration from estuarine headwaters. Being at the lower end of catchments, weirs on these systems have little impact on freshwater fish populations, and, as is the case in many other southern hemisphere countries, there are no anadromous species to be affected. Consequently, coastal weirs have received little environmental consideration. They do, however, form potential barriers to movement of marine and estuarine species. Fish species affected are euryhaline marine rather than freshwater forms, and are juveniles migrating to nursery 


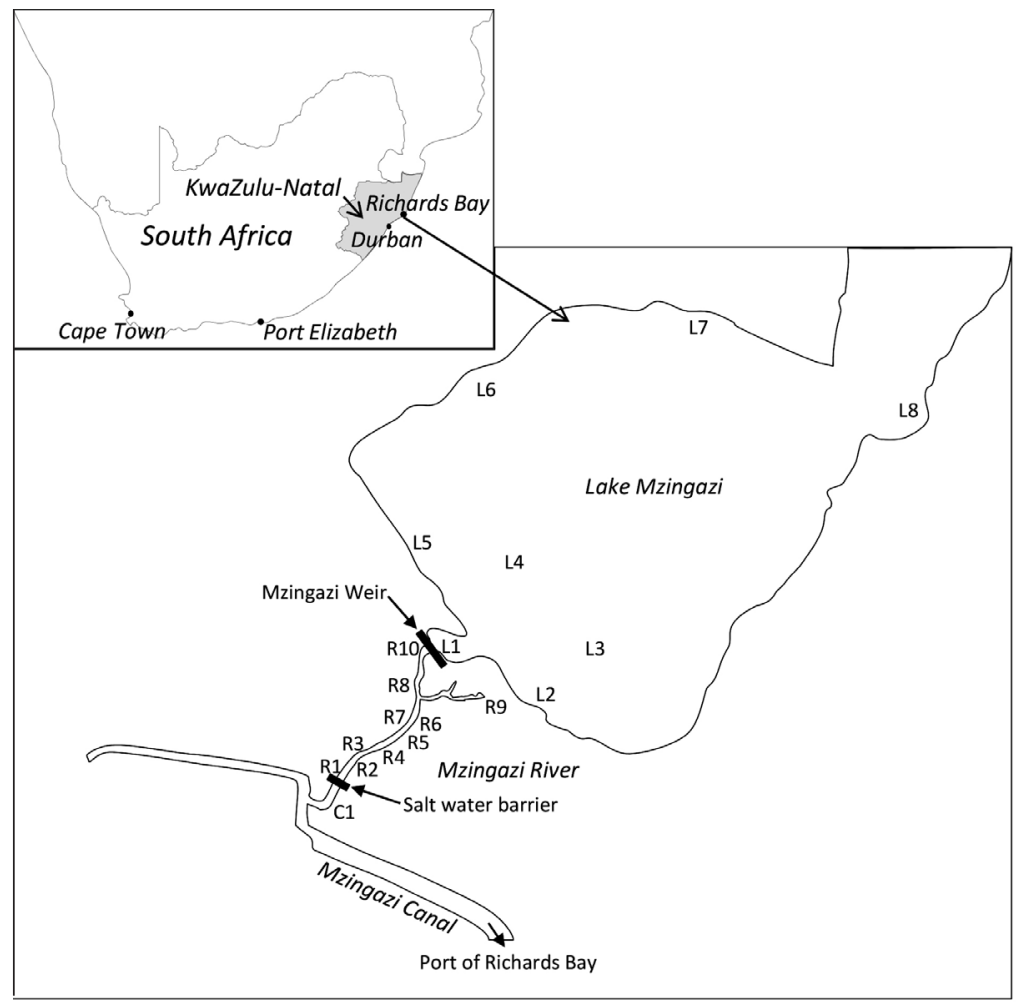

Figure 1

Study area showing three main components of the Mzingazi system. Location of sampling stations indicated.

$C$ - canal, $R$ - river, L-lake. habitats rather than adults migrating to spawning habitats. These are typically facultative catadromous species. Migration into freshwater is not essential for the completion of their life cycles. Nevertheless barriers in lowland waterways can affect their populations, both locally and regionally. In the Eastern Cape the natural ranges of catadromous mullet Myxus capensis have been markedly reduced in rivers as a result of weirs (Bok, 1979) and instream barriers have impacted the upstream distribution of other marine-spawned species (Wasserman et al., 2011). Crustaceans that rely on connectivity between marine, estuarine and freshwater systems are also important components of the aquatic fauna in coastal freshwaters. Impacts of barriers to migration amongst these systems are therefore important to understand. This, and the potential use of fish ladders in addressing this impact, has been little studied.

This study aimed to assess the potential ecological benefits of installing a fishway on the outlet weir of Lake Mzingazi, a coastal lake at Richards Bay on the east coast of South Africa (Fig. 1). The greater Richards Bay area is characterised by a set of coastal lakes that have all had their outlets dammed and raised over the last $70+$ years to maximise abstraction yields. Historically, these lakes served as nursery areas for marine and estuarine fishes that recruited from the original Richards Bay Lagoon (Weerts and Cyrus, 2001). Similar coastal lakes are found elsewhere in South Africa (Harding, 1992), east Africa (Hart and Boane, 2004), west Africa (Blaber, 1988) and Madagascar. These lakes typically have some degree of marine connectivity impacted or threatened by weirs built in response to increasing water demand.

\section{Study site}

Lake Mzingazi is a relict estuarine lake with a surface area of $12.16 \mathrm{~km}^{2}$ and a catchment of $164 \mathrm{~km}^{2}$ (Harding, 2000). It is fed by several small coastal streams. Lake level was first raised in 1943 by the construction of a berm, and subsequent modifications have seen the water level raised by $\sim 2 \mathrm{~m}$. The outlet is a vertical drop spillway which drains into a short section of the Mzingazi River. This in turn flows into the Mzingazi Canal which flows into the Port of Richards Bay, South Africa's largest commercial port. Depths in the lake fall below mean sea level (Kelbe and Germishyuse, 2000). This prompted the construction of a saltwater barrier across the Mzingazi River below the lake to prevent possible intrusion of saline water into the system during drought years. Saline water pushing up the Mzingazi Canal with incoming tides is now blocked by this barrier (Fig. 2).

The saltwater barrier potentially constitutes an obstacle to the upstream movement of estuarine and marine fishes and crustaceans. As a mitigation measure a sluice was incorporated into the design so that some tidal flow bypasses the barrier on tides rising $+0.805 \mathrm{~m}$ above sea level (Chart Datum). There is no such mitigation measure at the outflow point of the lake (Mzingazi Weir). The base of this weir is approximately $2 \mathrm{~km}$ above the saltwater barrier. The vertical drop spillway represents the only outflow point under normal water level conditions. However, during extreme floods overflow can occur via a natural drainage line which empties into the tail-water pool below the weir. For the purposes of this study, the system was considered in 3 sections (Fig. 1):

- Mzingazi Canal: A tidal canal flowing into the Port of Richards Bay. Water physico-chemical properties are estuarine, becoming increasingly marine towards the port.

- Mzingazi River: A short section of river upstream of the saltwater barrier but downstream of the lake.

- Mzingazi Lake: A coastal lake with an artificial raised water level and outlet comprising a vertical drop spillway.

\section{METHODS AND MATERIALS}

Physico-chemical water parameters were recorded in different reaches of the Mzingazi system using a Hydrolab Water 


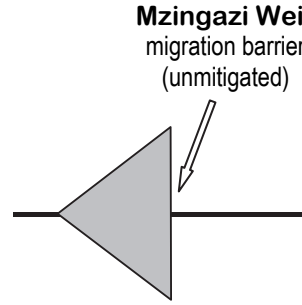

Lake Mzingazi
Saltwater Barrier

migration barrier

(mitigated)

B)

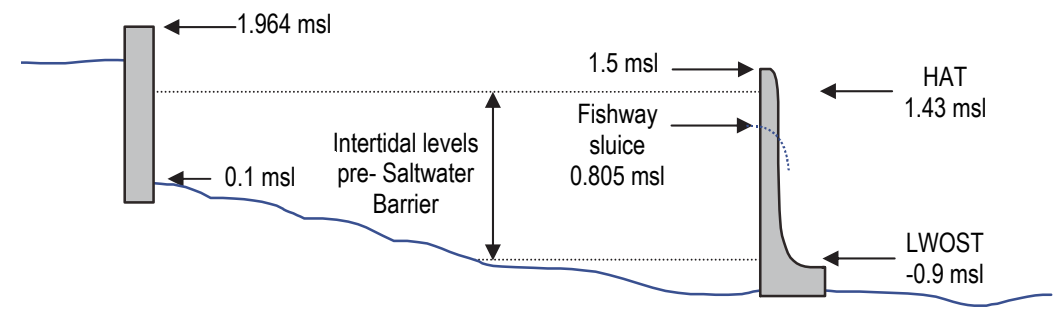

Figure 2

A) Diagrammatic representation of the Mzingazi system showing sections sampled and barriers to faunal migrations. B) Weir and barrier elevations and tidal heights (Chart Datum).
Quality Multiprobe. This allowed in-situ measurements of depth, temperature, conductivity, salinity, $\mathrm{pH}$ and dissolved oxygen. Water samples were returned to the laboratory and analysed for turbidity.

Various sampling methods were employed, including 2 small seine nets ( $1.5 \mathrm{~m}$ depth, $8 \mathrm{~m}$ length) of different mesh sizes ( $1 \mathrm{~mm}$ bar mesh and $4 \mathrm{~mm}$ bar mesh) and a medium seine net (6 $\mathrm{mm}$ bar mesh bag, $1.5 \mathrm{~m}$ depth, $30 \mathrm{~m}$ length). Gill netting was conducted using 50, 75 and $100 \mathrm{~mm}$ stretch mesh monofilament panels soaked for a minimum of $3 \mathrm{~h}$. An electro-fishing device ('electro-shocker') was used where gilland seine nets could not be effectively deployed and below the spillway of the Mzingazi Weir a cast net was also used. Fish and crustaceans that could be positively identified in the field were measured, recorded and returned live to the water. Others were preserved in $4 \%$ formaldehyde solution and returned to the laboratory for species verification and measurement. All catches were standardised to appropriate catch per unit effort (CPUE).

Sampling was conducted in September 2001 and March 2002 at locations indicated in Fig. 1. To supplement results from fieldwork, data were sourced from previous surveys of the system. These historical data allowed a wider array of species to be accounted for in the analysis. Some species were assumed to occur based on published and unpublished data from other systems in the area, as well as known biologies of species involved. These animals were only included when their occurrence was predicted with high confidence.

The distribution of fishes and crustaceans was considered in the context of their dependence on marine, estuarine and freshwater environments. Many estuarine-dependent marine species recruit into the Port of Richards Bay in early spring (Weerts and Cyrus, 2002, Weerts et al., 2003). Whitfield (1998) has categorised southern Africa's estuarine fishes according to their affinities for these environments (Table 1). These Estuarine Association Categories (EACs) were used to classify fish species occurring in the Mzingazi system. To account for stenohaline freshwater species, which have no affinity for estuarine habitats, the approach was modified to include an extra category (EAC VI, Table 1). Crustaceans were classified as being marine/estuarine (ME), marine/freshwater (MF), estuarine/freshwater (EF) or strictly freshwater species (F), based on published information on their breeding biologies and life histories (Barnard, 1950; Coetzee, 1988; Cort and Schoonbee; 1993, De Villiers et al., 1999).

\section{RESULTS}

\section{Water physico-chemistry parameters}

Salinity and specific conductivity varied markedly in the system (Table 2). Highest salinities were recorded in the Mzingazi Canal due to the tidal influence of marine water. In the river saline water was largely restricted to deeper sections $(>1.5 \mathrm{~m})$ of the lower reaches. Low dissolved oxygen levels were recorded in bottom waters of several deeper sections of the river, with particularly deep waters even becoming hypoxic $(<2 \mathrm{mg} / \ell)$. Water in the lake was fresh and oxygen content remained above $5 \mathrm{mg} / \ell$ and $70 \%$ saturation, even in water over $3 \mathrm{~m}$ in depth. Turbidities in the lake, as well as the river, were low, generally below 2 NTU.

\section{Fish}

Fifty-four fish taxa were collected during fieldwork (Table 3) but, based on previous surveys of the Mzingazi system and other lakes, rivers and estuaries in the greater Richards Bay region (Cyrus, 2001a; MacKay et al., 2001; Weerts and Cyrus, 2001), at least 70 species have been recorded, or are likely to occur. Ten of these are endemic to southern Africa and ten are listed on the International Union for the Conservation of Nature and Natural Resources Red List of Threatened Species (IUCN, 2012).

In the canal, estuarine species (EAC I) dominated seine net catches (Table 3). Estuarine-dependent marine fishes (EAC II) were also abundant and predominantly comprised of young fish that had recently recruited into the system via the port. Euryhaline freshwater fish (Mozambique tilapia Oreochromis mossambicus, EAC IV) occurred below the saltwater barrier but no stenohaline freshwater fishes (EAC VI) were sampled in Mzingazi Canal.

Seine net catches from the river above the saltwater barrier were also dominated by estuarine species (Table 3). Gill and cast-net catches predominately comprised euryhaline freshwater O. mossambicus but included several estuarine-dependent marine species. Fishes in this latter category occurred as late juveniles or adults and included milkfish Chanos chanos, evenfin pursemouth Gerres methueni, bigeye kingfish Caranx 
TABLE 1

The major life cycle categories of fishes and crustaceans utilising the Mzingazi system. Fish Estuarine Association Category (EAC) I to V from Whitfield (1998) modified to include EAC VI as described. Crustacean categories from referenced literature regarding biologies of taxa involved.

\begin{tabular}{|l|l|l|}
\hline EAC & Description \\
\hline & Fishes \\
\hline I & Estuarine species which breed in estuaries: \\
\hline & I a $\quad$ Resident species which have not been recorded spawning in marine or freshwater environments \\
\hline & I b $\quad$ Resident species which have been recorded spawning in marine or freshwater environments \\
\hline II & Euryhaline marine species which breed at sea but with juveniles that show varying degrees of dependence on estuaries \\
\hline & II a $\quad$ Juveniles dependent on estuaries as nursery areas \\
\hline & II b $\quad$ Juveniles occur mainly in estuaries but are also found at sea \\
\hline & II c & Juveniles occur in estuaries but are usually more abundant at sea \\
\hline III & Marine species which occur in estuaries in small numbers but are not dependent on these systems \\
\hline IV & Euryhaline freshwater species. Includes some species which may breed in both freshwater and estuarine environments \\
\hline V & Catadromous species which use estuaries as transit routes between the marine and freshwater environments \\
\hline & V a $\quad$ Obligate catadromous species which require a freshwater phase for their development \\
\hline & V b $\quad$ Facultative catadromous species which do not require a freshwater phase for their development \\
\hline VI & Stenohaline freshwater species with little or no tolerance for saline water \\
\hline & Crustaceans \\
\hline ME & Marine-spawned species with juvenile estuarine requirement \\
\hline MF & Marine-spawned species with juvenile to adult freshwater requirement \\
\hline EF & $\begin{array}{l}\text { Estuarine-spawned species or freshwater species dependent on estuarine (saline) influence during larval development and } \\
\text { upstream migration as post-larvae to freshwater habitat of adults }\end{array}$ \\
\hline F & Freshwater species capable of completing life cycles in freshwater \\
\hline
\end{tabular}

\begin{tabular}{|c|c|c|c|c|c|c|c|c|c|}
\hline \multicolumn{10}{|c|}{$\begin{array}{c}\text { TABLE } 2 \\
\text { Physico-chemical parameters recorded in situ at different locations in the Mzingazi system during March } 2002\end{array}$} \\
\hline $\begin{array}{l}\text { Site } \\
\text { no. }\end{array}$ & $\begin{array}{l}\text { Sample } \\
\text { depth }\end{array}$ & $\begin{array}{l}\text { Temp } \\
\left({ }^{\circ} \mathrm{C}\right)\end{array}$ & $\begin{array}{l}\text { Oxygen } \\
(\mathrm{mg} / \mathrm{l})\end{array}$ & $\begin{array}{l}\begin{array}{l}\text { Oxygen } \\
(\%)\end{array} \\
\text { (\%) }\end{array}$ & $\mathrm{pH}$ & $\begin{array}{l}\text { Conductivity } \\
(\mathrm{mS} / \mathrm{cm})\end{array}$ & Salinity & $\begin{array}{l}\text { Turbidity } \\
\text { (NTU) }\end{array}$ & $\begin{array}{l}\text { Depth } \\
\text { (m) }\end{array}$ \\
\hline C1 & mid & 28.86 & 5.03 & 81.5 & 7.74 & 35.400 & 23.1 & 4.8 & 1.0 \\
\hline R1 & top & 26.43 & 5.88 & 73.5 & 7.52 & 0.582 & 0.4 & \multirow[t]{2}{*}{1.6} & \multirow[t]{2}{*}{5.6} \\
\hline R1 & bottom & \begin{tabular}{|l|}
27.86 \\
\end{tabular} & 0.48 & 6.2 & 7.06 & 32.000 & 20.3 & & \\
\hline R2 & top & 26.22 & 5.85 & 65.6 & 7.56 & 0.575 & 0.3 & \multirow[t]{2}{*}{1.6} & \multirow[t]{2}{*}{1.8} \\
\hline R2 & bottom & 26.62 & 0.52 & 6.6 & 7.06 & 36.000 & 15.0 & & \\
\hline R3 & top & 26.42 & 6.25 & 65.6 & 7.56 & 0.545 & 0.3 & \multirow[t]{2}{*}{1.5} & \multirow[t]{2}{*}{2.6} \\
\hline R3 & bottom & 28.56 & 1.58 & \begin{tabular}{|l|}
17.4 \\
\end{tabular} & 6.77 & 23.500 & 15.8 & & \\
\hline $\mathrm{R} 4$ & top & 26.23 & 6.29 & 78.3 & 7.49 & \begin{tabular}{|l|}
0.539 \\
\end{tabular} & 0.3 & \multirow[t]{2}{*}{1.4} & \multirow[t]{2}{*}{1.5} \\
\hline $\mathrm{R} 4$ & bottom & 26.06 & 6.45 & 79.4 & \begin{tabular}{|l|}
7.49 \\
\end{tabular} & 0.526 & \begin{tabular}{|l|}
0.3 \\
\end{tabular} & & \\
\hline R5 & top & 26.17 & 6.31 & 74.7 & 7.50 & 0.463 & 0.3 & \multirow[t]{2}{*}{1.6} & \multirow[t]{2}{*}{2.3} \\
\hline R5 & bottom & 28.39 & 2.94 & 37.0 & 6.68 & 17.300 & 8.9 & & \\
\hline R6 & top & 26.23 & 6.33 & 77.8 & \begin{tabular}{|l|}
7.47 \\
\end{tabular} & 0.444 & 0.2 & \multirow[t]{2}{*}{1.6} & \multirow[t]{2}{*}{1.4} \\
\hline R6 & bottom & 25.97 & 6.50 & 80.5 & 7.50 & 0.472 & 0.3 & & \\
\hline R7 & top & 26.30 & 5.74 & 73.6 & 6.79 & 0.423 & 0.2 & \multirow[t]{2}{*}{1.6} & \multirow[t]{2}{*}{2.3} \\
\hline R7 & bottom & 27.30 & 0.19 & 5.4 & 6.91 & 7.020 & 5.1 & & \\
\hline R8 & top & 26.10 & 3.18 & 48.0 & 7.02 & 2.650 & 0.4 & \multirow[t]{2}{*}{1.5} & \multirow[t]{2}{*}{1.9} \\
\hline R8 & bottom & 26.17 & 0.27 & 5.8 & 7.05 & 4.250 & 1.2 & & \\
\hline R9 & mid & 27.22 & 3.19 & 39.0 & 6.95 & 0.562 & 0.3 & 2.9 & 1.4 \\
\hline R10 & mid & 26.81 & 6.85 & 85.2 & 7.59 & 0.361 & 0.2 & 1.8 & 1.0 \\
\hline L1 & mid & 26.85 & 5.64 & 71.7 & 7.48 & 0.361 & 0.2 & 1.2 & 0.8 \\
\hline $\mathrm{L} 2$ & mid & 27.45 & 5.39 & 68.3 & 7.37 & 0.352 & 0.2 & 1.4 & 1.4 \\
\hline L3 & top & 26.64 & 7.86 & 97.8 & \begin{tabular}{|l|}
8.49 \\
\end{tabular} & 0.358 & 0.2 & \multirow[t]{2}{*}{1.5} & \multirow[t]{2}{*}{3.0} \\
\hline L3 & bottom & 26.34 & 7.09 & 79.9 & 8.46 & 0.359 & 0.2 & & \\
\hline L4 & top & 26.52 & \begin{tabular}{|l|}
7.39 \\
\end{tabular} & 92.1 & 8.29 & \begin{tabular}{|l|}
0.357 \\
\end{tabular} & 0.2 & \multirow[t]{2}{*}{1.2} & \multirow[t]{2}{*}{3.1} \\
\hline L4 & bottom & 26.30 & 7.66 & 93.5 & 8.33 & 0.358 & 0.2 & & \\
\hline L6 & mid & 28.88 & 7.93 & 100.5 & 8.51 & 0.359 & 0.2 & - & 0.6 \\
\hline L7 & mid & 29.16 & 7.21 & 95.4 & 7.80 & \begin{tabular}{|l|}
0.359 \\
\end{tabular} & 0.2 & - & 0.6 \\
\hline L8 & mid & 28.51 & 8.60 & 109.5 & 8.69 & 0.358 & 0.2 & 1.7 & 0.5 \\
\hline
\end{tabular}




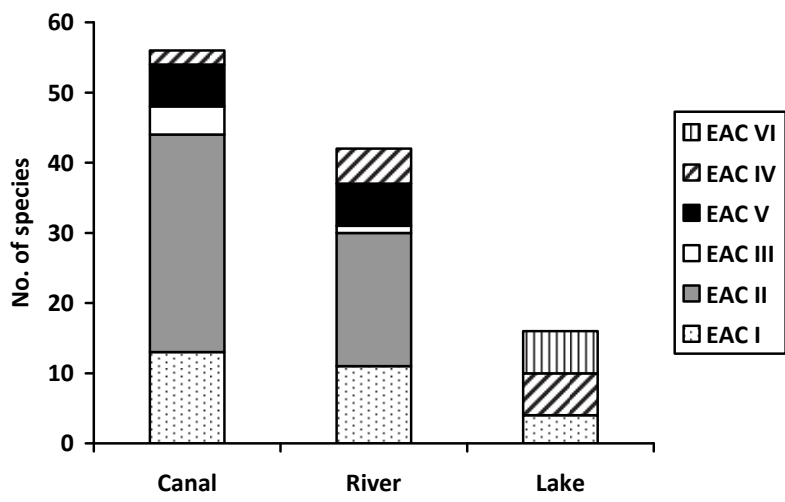

Figure 3

Numbers of fish taxa in the Mzingazi system. Contributions from different estuarine association categories indicated. Categories I to VI as described in Table 1.

sexfasciatus and diamond mullet Liza alata. Catadromous fishes sampled were M. capensis and Madagascar mottled eel Anguilla marmorata. These and other estuarine and marinespawned fishes occurred in highest densities in the tail-water pool directly below the Mzingazi Weir spillway. No stenohaline freshwater species were sampled in the river.

Six stenohaline freshwater fish species were reported from the lake. However, euryhaline freshwater cichlids (O. mossambicus, banded tilapia Tilapia sparrmanii and southern mouthbrooder Pseudocrenilabrus philander) were the most abundant fishes sampled by small seine. Medium seine and electroshocker catches were dominated by species typically associated with estuaries and coastal freshwaters (estuarine roundherring Gilchristella aestuaria, dusky sleeper Eleotris fusca and river goby Glossogobius callidus). No marine species were recorded in the lake. Catadromous species were the focus of this investigation and, in order to target mullet that would potentially use open water habitat, gill nets were set away from vegetation in the lake. Zero catches were recorded. However, gill nets laid by subsistence fishers in closer proximity to the shoreline vegetation in the lake are known to yield high numbers of tilapias and catfish (Ezemvello KZN Wildlife observations).

The number of fish species utilising different sections of the Mzingazi system decreased markedly with the change from estuarine conditions in the canal (56 species) to freshwater in the lake (16 species, Fig. 3). This was mostly due to declines in the occurrence of marine-spawning species (EAC II and V). Sampling conducted in the lake yielded none of the estuarine-dependent marine species (EAC II) or catadromous fishes (EAC V) which are known to migrate into freshwaters, despite an abundance of these fishes in the canal and river. Conversely, primary freshwater species (EAC VI) only occurred in the lake and were absent downstream of the Mzingazi Weir. Data from other coastal lakes and knowledge of the biologies of fishes of the region indicated that many more species could potentially utilise Lake Mzingazi than is presently the case, should connectivity between the river and the lake be restored (Table 3). These species are all euryhaline forms which rely on migration into freshwaters as juveniles from estuarine or marine spawning grounds.

\section{Crustaceans}

Crabs, shrimps and prawns collected in the Mzingazi system are listed in Table 4. At least 19 of 24 taxa likely to occur were sampled during this study. Species not sampled were mostly

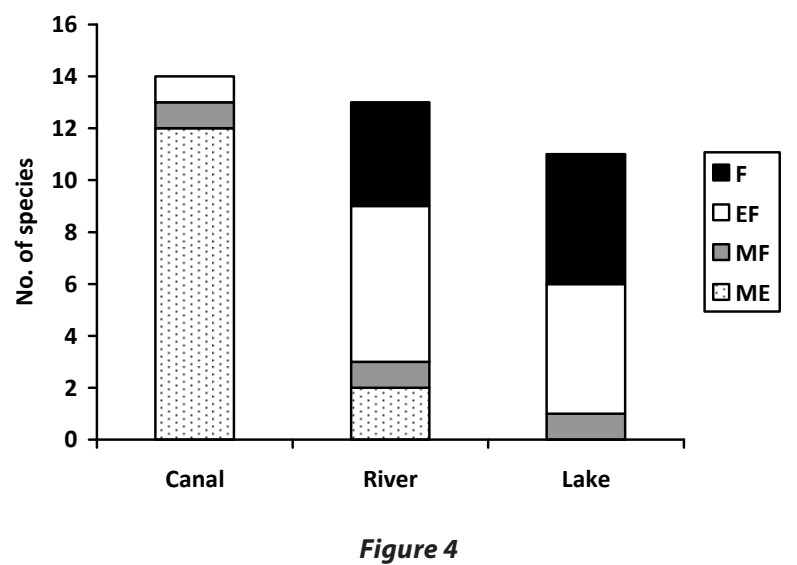

Numbers of crustacean taxa in the Mzingazi system. Life cycle categories as described in Table 1.

marine spawning crustaceans that are known to utilise the upper reaches of the Mzingazi Canal. This was a reflection of selectivity in sampling gear rather than the absence of these taxa. For example, burrows of fiddler crabs Uca spp., Sesarmid mangrove crabs and sandprawn Callichirus kraussi were noted below the saltwater barrier, but none were caught using seine nets. The sampled fauna was dominated by Fenneropenaeus indicus, one of at least four penaeid prawn species known to occur in the canal. Only two of these prawn species were recorded above the saltwater barrier, where they occurred in low abundances compared to the shrimp Palaemon concinnus. Freshwater prawns (Macrobrachium spp.) were absent as juveniles and adults in the canal, but became increasingly abundant with distance upstream. They occurred in highest numbers directly above the outlet weir in the lake. The crab Varuna litterata occurred in highest densities in the lake, although it was recorded in all three sections of the system. All specimens recorded above the saltwater barrier were adult.

The number of crustacean species in the Mzingazi system decreased with the change from estuarine conditions in the canal to freshwater in the lake (Fig. 4). This was due to a sharp reduction in marine-spawning forms. Only 3 of these species recruited into the river reaches although at least 13 occur directly below the saltwater barrier. Varuna litterata is the only marine-spawning crustacean that occurs upstream of the Mzingazi Weir. Losses of marine crustaceans upstream of the saltwater barrier were offset by increases in freshwater Macrobrachium prawns (which have larval stages dependent on some salinity influence) and freshwater shrimps of the genus Caridina. In terms of catch abundances marine-spawning crustaceans that utilise estuaries as juveniles decreased from canal to lake, whilst freshwater species (including those with larval stages dependent on brackish water) contributed greater proportions to crustacean communities in the river and lake (Table 4).

\section{DISCUSSION}

\section{Impacts of loss of marine-estuarine-freshwater connectivity at Lake Mzingazi}

The salinity regime of the Mzingazi Canal is typically estuarine, fluctuating tidally and depending on freshwater inflow from Mzingazi River. The fish bypass sluice on the saltwater barrier allows saline water inflow into the lower river over 
TABLE 3

Fishes in the Mzingazi system. Figures are percentage contribution of each taxon to total catch reported for different sampling gears from fieldwork conducted during this study. $\checkmark=$ species not reported during this study, but previously recorded (CRUZ unpublished data, MacKay et al., 2001, Weerts and Cyrus, 2001 and references therein), $x=$ species not sampled but likely to occur, $\otimes=$ species occurrence dependent on connectivity being restored. Estuarine Association Categories (EAC's) as described in Table 1. ${ }^{*}=$ endemic to southern Africa (Whitfield, 1998), \# = threatened species (IUCN, 2012).

\begin{tabular}{|c|c|c|c|c|c|c|c|c|c|c|c|}
\hline \multirow[t]{2}{*}{ Taxon } & \multirow[t]{2}{*}{ EAC } & \multicolumn{2}{|l|}{ Canal } & \multicolumn{5}{|l|}{ River } & \multicolumn{3}{|l|}{ Lake } \\
\hline & & $\begin{array}{l}\text { Fine } \\
\text { seine }\end{array}$ & \begin{tabular}{|l} 
Med \\
seine
\end{tabular} & $\begin{array}{l}\text { Small } \\
\text { seine }\end{array}$ & $\begin{array}{l}\text { Med } \\
\text { seine }\end{array}$ & $\begin{array}{l}\text { Gill } \\
\text { net }\end{array}$ & $\begin{array}{l}\text { Electro- } \\
\text { shocker }\end{array}$ & $\begin{array}{l}\text { Cast } \\
\text { net }\end{array}$ & $\begin{array}{l}\text { Small } \\
\text { seine }\end{array}$ & $\begin{array}{l}\text { Med } \\
\text { seine }\end{array}$ & $\begin{array}{l}\text { Electro- } \\
\text { shocker }\end{array}$ \\
\hline Gilchristella aestuaria * & I a & 0.2 & & \multicolumn{5}{|c|}{$\checkmark$} & 7.6 & 98.3 & \\
\hline Hyporhamphus capensis * & I a & \multicolumn{2}{|c|}{$\checkmark$} & \multicolumn{5}{|c|}{$\checkmark$} & & 0.2 & \\
\hline Glossogobius biocellatus \# & I a & & 0.4 & & & & & & & & \\
\hline Glossogobius tenuiformis & I a & 20.6 & 2.2 & 5.7 & 51.5 & & 20.0 & & & & \\
\hline Oligolepis acutipennis & I a & 1.5 & 5.2 & \multicolumn{5}{|c|}{$\checkmark$} & & & \\
\hline Oligolepis keiensis \# & I a & 2.8 & & & & & & & & & \\
\hline Eleotris fusca \# & I a & & & 1.0 & & & 40.0 & & & & 42.9 \\
\hline Ambassis ambassis & I a & \multicolumn{2}{|c|}{$\checkmark$} & 60.9 & 13.6 & & 20.0 & 17.1 & & 田 & \\
\hline Ambassis dussumieri & $\mathrm{Ib}$ & 7.9 & 50.2 & 13.2 & & & & & & & \\
\hline Ambassis natalensis & $\mathrm{Ib}$ & 8.8 & 4.4 & 4.6 & 13.6 & & & & & & \\
\hline Croilia mossambica *\# & $\mathrm{Ib}$ & 11.2 & & & 1.5 & & & & \multicolumn{3}{|c|}{$\checkmark$ 口 } \\
\hline Favonigobius melanobranchus \# & $\mathrm{Ib}$ & \multicolumn{2}{|c|}{$\checkmark$} & & & & & & & & \\
\hline Favonigobius reichei \# & $\mathrm{Ib}$ & 1.2 & 0.4 & & & & & & & & \\
\hline Glossogobius callidus ${ }^{\star} \#$ & $\mathrm{Ib}$ & & & & & & & & 19.8 & 0.6 & 14.3 \\
\hline Microphis brachyurus & $\mathrm{Ib}$ & & & \multicolumn{5}{|c|}{$\checkmark$} & \multicolumn{3}{|c|}{$\mathbf{x}$} \\
\hline Microphis fluviatilis & $\mathrm{Ib}$ & & & & & & & & \multicolumn{3}{|c|}{ 田 } \\
\hline Silhouettea sibayi ${ }^{\star} \#$ & $\mathrm{Ib}$ & 7.3 & 5.7 & \multicolumn{5}{|c|}{$\mathrm{x}$} & & 圆 & \\
\hline Elops machnata & II a & 0.7 & & \multicolumn{5}{|c|}{$\checkmark$} & \multicolumn{3}{|c|}{ 目 } \\
\hline Terapon jarbua & II a & 0.3 & & & 6.1 & & & & & & \\
\hline Pomadasys commersonnii & II a & 0.2 & & \multicolumn{5}{|c|}{$\checkmark$} & \multicolumn{3}{|c|}{$\mathbf{x}$} \\
\hline Acanthopagrus vegas & II a & 0.1 & & \multicolumn{5}{|c|}{$\checkmark$} & & 田 & \\
\hline Rhabdosargus holubi ${ }^{*}$ & II a & 0.1 & & & & $\checkmark$ & & & & 田 & \\
\hline Liza macrolepis & II a & 0.3 & 0.4 & & & $\checkmark$ & & & & 圆 & \\
\hline Mugil cephalus & II a & 2.5 & & & & $\mathrm{x}$ & & & & 田 & \\
\hline Valamugil cunnesius & II a & 0.2 & & & & $\mathrm{x}$ & & & & 圆 & \\
\hline Valamugil robustus & II a & & 3.5 & & & $\mathrm{x}$ & & & & 国 & \\
\hline Liza alata & II b & & 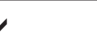 & & & 16.0 & & 14.3 & & 田 & \\
\hline Liza dumerilii & II b & & 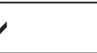 & & & $\checkmark$ & & & & & \\
\hline Monodactylus falciformis & II a & & 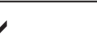 & & & $\mathrm{x}$ & & & & 圆 & \\
\hline Monodactylus argenteus & II b & & 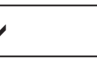 & & & $\checkmark$ & & & & $\mathbf{x}$ & \\
\hline Sphyraena barracuda & II b & & 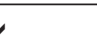 & & & & & & & & \\
\hline Thryssa sp. & II b & 0.1 & & & & & & & & & \\
\hline Rhabdosargus sarba & II b & 0.3 & & & & & & & & 目 & \\
\hline Gerres spp. (incl. G. methueni ${ }^{*}$ ) & II b & 8.7 & 1.3 & 0.5 & & 3.7 & & & & 目 & \\
\hline Leiognathus equula & II b & 0.6 & & & & & & & & & \\
\hline Caranx sexfasciatus & II b & 0.1 & & & & 4.7 & & & & 国 & \\
\hline Solea turbynei ${ }^{*}$ & II b & 1.2 & 4.4 & & 1.5 & & & & & & \\
\hline Chanos chanos & II c & & 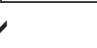 & & & 10.9 & & & & 圆 & \\
\hline Hilsa kelee & II c & 0.2 & & & & & & & & & \\
\hline Diplodus capensis * & II c & & 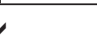 & & & & & & & & \\
\hline Stolephorus holodon & II c & 9.0 & 0.4 & & & & & & & & \\
\hline Stolephorus indicus & II c & 10.0 & 0.4 & & & $\checkmark$ & & & & & \\
\hline Strongylura leiura & II c & & 0.4 & & & & & & & & \\
\hline
\end{tabular}




\begin{tabular}{|c|c|c|c|c|c|c|c|c|c|c|c|}
\hline \multicolumn{12}{|c|}{$\begin{array}{l}\text { TABLE } 3 \\
\text { Fishes in the Mzingazi system. Figures are percentage contribution of each taxon to total catch reported for different sampling gears } \\
\text { from fieldwork conducted during this study. } \checkmark=\text { species not reported during this study, but previously recorded (CRUZ unpublished } \\
\text { data, MacKay et al., 2001, Weerts and Cyrus, } 2001 \text { and references therein), } x=\text { species not sampled but likely to occur, } 囚=\text { species } \\
\text { occurrence dependent on connectivity being restored. Estuarine Association Categories (EAC's) as described in Table } 1 .{ }^{*}=\text { endemic to } \\
\text { southern Africa (Whitfield, 1998), \# = threatened species (IUCN, 2012). }\end{array}$} \\
\hline \multirow[t]{2}{*}{ Taxon } & \multirow[t]{2}{*}{ EAC } & \multicolumn{2}{|l|}{ Canal } & \multicolumn{5}{|l|}{ River } & \multicolumn{3}{|l|}{ Lake } \\
\hline & & \begin{tabular}{|l}
$\begin{array}{l}\text { Fine } \\
\text { seine }\end{array}$ \\
\end{tabular} & \begin{tabular}{|l|}
$\begin{array}{l}\text { Med } \\
\text { seine }\end{array}$ \\
\end{tabular} & \begin{tabular}{|l|}
$\begin{array}{l}\text { Small } \\
\text { seine }\end{array}$ \\
\end{tabular} & $\begin{array}{l}\text { Med } \\
\text { seine }\end{array}$ & $\begin{array}{l}\text { Gill } \\
\text { net }\end{array}$ & \begin{tabular}{|l|}
$\begin{array}{l}\text { Electro- } \\
\text { shocker }\end{array}$ \\
\end{tabular} & \begin{tabular}{|l|} 
Cast \\
net
\end{tabular} & \begin{tabular}{|l|}
$\begin{array}{l}\text { Small } \\
\text { seine }\end{array}$ \\
\end{tabular} & $\begin{array}{l}\text { Med } \\
\text { seine }\end{array}$ & $\begin{array}{l}\text { Electro- } \\
\text { shocker }\end{array}$ \\
\hline Platycephalus indicus & II c & 0.8 & 0.9 & & & & & & & & \\
\hline Pomadasys kakaan & II c & 0.1 & 0.4 & & & & & & & & \\
\hline Lutjanus argentimaculatus & II c & \multicolumn{2}{|c|}{$\mathrm{x}$} & 0.2 & & & & & & & \\
\hline Lutjanus fulviflamma & II c & 0.1 & & & & & & & & & \\
\hline Sillago sihama & II c & 0.1 & & & & & & & & & \\
\hline Pomadasys olivaceum & III & \multicolumn{2}{|c|}{$\checkmark$} & 0.2 & & & & & & & \\
\hline Pseudorhombus arsius & III & 0.1 & 0.4 & & & & & & & & \\
\hline Chelonodon laticeps & III & 0.2 & 0.4 & & & & & & & & \\
\hline Arothron immaculatus & III & 0.5 & 4.4 & & & & & & & & \\
\hline Glossogobius giuris & IV & & & 2.5 & 12.1 & & & & \multicolumn{3}{|c|}{$\checkmark$} \\
\hline Oreochromis mossambicus & IV & 0.3 & 5.7 & & & 59.1 & & 68.6 & 16.7 & & \\
\hline Tilapia rendalli & IV & \multicolumn{2}{|c|}{$\checkmark$} & \multicolumn{5}{|c|}{$\mathrm{x}$} & \multicolumn{3}{|c|}{0.4} \\
\hline Tilapia sparrmanii & IV & & & & & & & & 24.3 & & \\
\hline Pseudocrenilabrus philander & IV & & & & & 5.6 & 10.0 & & 18.7 & 0.2 & 14.3 \\
\hline Clarias gariepinus & IV & & & \multicolumn{5}{|c|}{$\checkmark$} & \multicolumn{3}{|c|}{$\checkmark$} \\
\hline Anguilla bengalensis labiata & $\mathrm{Va}$ & \multicolumn{2}{|c|}{$\mathrm{x}$} & \multicolumn{5}{|c|}{$\mathrm{x}$} & \multicolumn{3}{|c|}{ 冈 } \\
\hline Anguilla bicolor bicolor & $\mathrm{Va}$ & \multicolumn{2}{|c|}{$\mathrm{x}$} & \multicolumn{5}{|c|}{$\mathrm{x}$} & \multicolumn{3}{|c|}{$\nabla$} \\
\hline Anguilla marmorata & $\mathrm{Va}$ & \multicolumn{2}{|c|}{$\mathrm{x}$} & & & & 10.0 & & \multicolumn{3}{|c|}{ 国 } \\
\hline Anguilla mossambica & $\mathrm{Va}$ & \multicolumn{2}{|c|}{$\mathrm{x}$} & \multicolumn{5}{|c|}{$\mathrm{x}$} & \multicolumn{3}{|c|}{ 冈 } \\
\hline Megalops cyprinoides & $\mathrm{Vb}$ & \multicolumn{2}{|c|}{$\checkmark$} & \multicolumn{5}{|c|}{$\checkmark$} & \multicolumn{3}{|c|}{$\checkmark$ 回 } \\
\hline Myxus capensis ${ }^{\star} \#$ & $\mathrm{Vb}$ & 1.8 & 8.3 & 11.1 & & & & & & $\checkmark$ 口 & \\
\hline Aplocheilichthys johnstoni & VI & & & & & & & & 9.4 & & 14.3 \\
\hline Aplocheilichthys katangae & VI & & & & & & & & & $\checkmark$ & \\
\hline Barbus paludinosus & VI & & & & & & & & & $\checkmark$ & \\
\hline Barbus viviparous & VI & & & & & & & & 3.5 & 0.4 & \\
\hline Clarias theodorae \# & VI & & & & & & & & & & 14.3 \\
\hline Marcusenius macrolepidotus & VI & & & & & & & & & $\checkmark$ & \\
\hline
\end{tabular}

spring high tides. This water moves up the river channel but, being heavier than freshwater, its influence is largely restricted to the deeper sections, and does not extend to Mzingazi Weir. Prior to the construction of the saltwater barrier the lower Mzingazi River experienced greater tidal fluctuation and was far more estuarine in character. Indeed, tidal intrusion of saline water had previously been recorded all the way to the base of the weir (Cyrus et al., 1997), although this was during a period of prolonged drought and negligible overflow from the lake. The degree to which saline intrusion ever occurred into the lake itself is unknown. Prior to the construction of the port at Richards Bay in the mid-1970s, a much shallower and narrower estuary mouth probably resulted in much smaller tidal variation in the lower Mzingazi River. An embankment at the lake outlet was first built in 1943 to raise lake level by $1 \mathrm{~m}$ (Fowles and Archibald, 1987). In 1955, the outlet was modified again to bring about a further $1.75 \mathrm{~m}$ increase in water level (Reavell and Cyrus, 1989) and an extra $0.5 \mathrm{~m}$ was provided by the addition of a plate at the outflow in 1996 (Serfontein, 2000).
Many estuarine and marine-spawning fish species occur in the Mzingazi Canal. The bypass sluice on the saltwater barrier permits upstream migration of several of these species, presumably in response to salinity or olfactory cues carried in the freshwater inflow. Such cues have been found to be important signals for fishes recruiting into estuaries (Boehlert and Mundy, 1988, James et al., 2008). Whether or not recruitment of these fishes into the lower reaches of the Mzingazi River is partially hindered by the saltwater barrier remains unknown. High abundances of young fishes (including larval and post-larval stages) below the saltwater barrier in this study suggested some bottlenecking of fishes trying to migrate upstream. The abundance of juvenile estuarine-dependent marine species in the river was also lower than expected, but this was at least partly due to sampling difficulties. These fishes were most likely to have been caught using seines, but the deployment of these nets was difficult in the river as there were few shallow sandbanks to sample. Schools of mullet were noted during the fieldwork, but relatively few of these fishes were seined. It is therefore likely 
TABLE 4

Crustaceans in the Mzingazi system. Figures are percentage contribution of each taxon to total catch reported for different sampling gears from sampling conducted during this study. $\checkmark=$ species not reported during this study, but previously recorded (CRUZ unpublished data, Reavell and Cyrus, 1989, MacKay et al., 2001, Weerts et al., 2003.), $x=$ species not sampled but likely to occur. Life cycle categories as described in Table 1.

\begin{tabular}{|c|c|c|c|c|c|c|c|c|}
\hline \multirow[t]{2}{*}{ Taxon } & \multirow{2}{*}{$\begin{array}{l}\text { Life } \\
\text { cycle }\end{array}$} & \multicolumn{2}{|c|}{ Canal } & \multicolumn{3}{|c|}{ River } & \multicolumn{2}{|c|}{ Lake } \\
\hline & & $\begin{array}{l}\text { Fine } \\
\text { seine }\end{array}$ & $\begin{array}{l}\text { Med } \\
\text { seine }\end{array}$ & $\begin{array}{l}\text { Small } \\
\text { seine }\end{array}$ & $\begin{array}{l}\text { Med } \\
\text { seine }\end{array}$ & $\begin{array}{l}\text { Electro- } \\
\text { shocker }\end{array}$ & $\begin{array}{l}\text { Small } \\
\text { seine }\end{array}$ & $\begin{array}{l}\text { Electro- } \\
\text { shocker }\end{array}$ \\
\hline Metapenaeus monoceros & ME & \multicolumn{2}{|c|}{$\checkmark$} & 0.8 & & & & \\
\hline Fenneropenaeus indicus & $\mathrm{ME}$ & 98.8 & 96.3 & & & & & \\
\hline Marsupenaeus japonicus & $\mathrm{ME}$ & & 2.4 & & & & & \\
\hline Penaeus monodon & ME & \multicolumn{2}{|c|}{$\checkmark$} & 0.5 & & & & \\
\hline Callichirus kraussi & $\mathrm{ME}$ & \multicolumn{2}{|c|}{$\checkmark$} & & & & & \\
\hline Clibanarius longitarsus & $\mathrm{ME}$ & \multicolumn{2}{|c|}{$\checkmark$} & & & & & \\
\hline Hymenosoma orbiculare & ME & 0.4 & & & & & & \\
\hline Scylla serrata & $\mathrm{ME}$ & 0.4 & & & & & & \\
\hline Dorippe sp. & $\mathrm{ME}$ & & 1.2 & & & & & \\
\hline Dotilla fenestrata & $\mathrm{ME}$ & \multicolumn{2}{|c|}{$\checkmark$} & & & & & \\
\hline Sesarmid spp. & $\mathrm{ME}$ & \multicolumn{2}{|c|}{$\checkmark$} & & & & & \\
\hline Uca spp. & $\mathrm{ME}$ & \multicolumn{2}{|c|}{$\checkmark$} & & & & & \\
\hline Varuna litterata & $\mathrm{MF}$ & 0.4 & & 0.4 & 100.0 & 2.0 & 78.9 & 0.5 \\
\hline Palaemon concinnus & $\mathrm{EF}$ & \multicolumn{2}{|c|}{$\checkmark$} & 81.2 & & 35.3 & & \\
\hline Macrobrachium equidens & $\mathrm{EF}$ & & & 5.1 & & 32.4 & & 1.6 \\
\hline Macrobrachium idae & $\mathrm{EF}$ & & & 0.2 & & & & 2.1 \\
\hline Macrobrachium lepidactylus & $\mathrm{EF}$ & & & \multicolumn{3}{|c|}{$\mathrm{x}$} & & 12.4 \\
\hline Macrobrachium rude & EF & & & 0.4 & & 2.0 & & 0.5 \\
\hline Macrobrachium scabriculum & EF & & & & & 6.9 & & 9.3 \\
\hline Macrobrachium spp. & $\mathrm{EF}$ & & & & & 4.9 & & 7.8 \\
\hline Caridina africana & $\mathrm{F}$ & & & \multicolumn{3}{|c|}{$\mathrm{x}$} & & 0.5 \\
\hline Caridina indistincta & $\mathrm{F}$ & & & & & 2.0 & 10.5 & 1.6 \\
\hline Caridina nilotica & $\mathrm{F}$ & & & 11.5 & & 13.7 & 10.5 & 63.7 \\
\hline Caridina typus & $\mathrm{F}$ & & & & & 1.0 & \multicolumn{2}{|c|}{$\mathrm{X}$} \\
\hline Potamonautes sidneyi & $\mathrm{F}$ & & & & & & \multicolumn{2}{|c|}{$\checkmark$} \\
\hline
\end{tabular}

that more estuarine-dependent marine species utilise Mzingazi River than indicated by the data presented. Aside from those sampled during this survey others that occur are largescale mullet Liza macrolepis, oxeye tarpon Megalops cyprinoides, ladyfish Elops machnata, round moony Monodactylus argenteus and estuarine bream Acanthopagrus vegas. These species all tolerate, and in some cases have documented preferences for, freshwater habitats as nursery areas (Whitfield et al., 1981; Whitfield, 1998). The weir at Lake Mzingazi outlet prevents these fishes migrating further upstream. The concentration of fishes in the tail-water pool below the lake weir suggests that utilisation of lake waters would occur should recruitment into the system be possible.

There are no published records of the fish fauna of Lake Mzingazi prior to outlet modification. Several estuarine species occur in the present system (e.g. Knysna halfbeak Hyporhamphus capensis, G. aestuaria and G. callidus). These species, together with E. fusca, are breeding in the lake and are not recruiting into the system from estuarine or marine spawning grounds. However, C. sexfasciatus, M. cyprinoides and M. capensis, reported in 1985 and 1993 (Weerts and Cyrus, 2001), are species that cannot complete their life cycles in freshwater and therefore must have recruited to Lake Mzingazi from marine spawning grounds. The sizes of these sampled fishes indicated that their presence in the lake could be attributed to recruitment as juveniles during major flood events in 1984 and 1987. During these floods overflow from the lake occurred via a natural drainage line around the weir. It appears that this can be used by fishes to recruit up the system, but only during episodic flood events. Clearly these fishes, as well as several other species with known affinities for freshwater habitats in KwaZulu-Natal, will utilise Lake Mzingazi as juveniles if they are afforded the opportunity to recruit into the system.

A diverse assemblage of marine-spawning crustaceans also recruit into the upper reaches of Mzingazi Canal. The highest diversity of estuarine crustaceans in the Port of Richards Bay occurs in canals with freshwater inflows (Weerts et al., 2003). The Mzingazi Canal serves as a nursery area for these species but relatively few of them establish significant numbers above the saltwater barrier. It is possible that most prawns and crabs move upstream into estuarine headwaters much closer to the substratum than do fishes, which use the water column. The bypass sluice at the saltwater barrier could be much less userfriendly for estuarine crustaceans, explaining their paucity 
in the river compared with estuarine fishes. Reduced salinity above the barrier, however, is likely to play a larger role. Penaeids dominated the crustaceans below the barrier. With the exception of Metapenaeus monoceros, these prawns do not readily enter freshwater habitats in southern Africa (De Villiers et al., 1999). It is therefore probable that ambient physicochemical parameters govern their penetration up the Mzingazi system rather than physical barriers to recruitment.

In contrast, the crab Varuna litterata is known to recruit into coastal freshwater systems from marine waters (Connell and Robertson, 1986). Migration to freshwater is an obligatory part of this crab's life cycle (MacKay and Cyrus, 2001) and its megalop larvae are highly efficient swimmers which penetrate considerable distances into freshwater systems (pers obs.). Varuna litterata clearly needs to overcome the Mzingazi Weir in order to recruit to the lake habitats upstream.

Larvae of Macrobrachium prawn species in the Mzingazi system are dependent on saline water (typically salinities of 8-10) to pass through their early developmental stages (Subramanian et al., 1980; Cort and Schoonbee, 1993; Short, 2004). It is uncertain whether these larvae are transported downstream to estuarine headwaters by river flow, or whether adults are catadromous and migrate downstream to breed. It is likely that variation exists between and within species (Cort and Schoonbee, 1993). However, the fact that all these species have larvae which initially develop in brackish water is important as it implies that these prawns must all recruit into freshwater habitats from the lower river reaches or the Mzingazi Canal.

Little is known of the biology of Palaemon concinnus in South African waters. Elsewhere the species appears to exist in marine, estuarine or freshwater forms (De Grave et al., 2008; Ashelby et al., 2012). In Mozambique it has been found to have a high affinity for estuarine areas and mangrove habitats in particular (Hughes, 1966), where it appears to complete its life cycle (Penha-Lopes et al., 2011). Although not reported from the Port of Richards Bay (Weerts et al., 2003) the species has previously been sampled in the Mzingazi Canal and occurs in abundance as juveniles in beds of seagrass Zostera capensis in the adjacent Mhlathuze Estuary (Weerts, pers. obs.). Bruton and Appleton (1975) found P. concinnus to be common as adults in Lake Mgobezeleni and abundant as juveniles in the linked estuary downstream. It appears, therefore, that in the region $P$. concinnus is estuarine spawning but has an affinity for lacustrine coastal freshwater habitats.

From the above it is clear that the weir at Lake Mzingazi has negative ramifications for 2 main groups of crustaceans; a marine spawning crab (V. litterata) and a suite of palaemonid prawns (P. concinnus and Macrobrachium spp.), which either spawn in or have larvae dependant on estuarine water. Varuna litterata and Macrobrachium prawns are not completely restricted by the weir in its present form and clearly overcome the barrier to migrate successfully into the lake from the lower river reaches. Varuna litterata are known to overcome considerable barriers to migration during mass larval recruitment episodes. They have been observed leaving water to travel over land for short distances (Ryan and Choy, 1990), and crawling up vertical faces of dams and weirs (pers. obs.). Macrobrachium prawns also have the ability to overcome the Mzingazi Weir as a barrier to upstream migration, either as larvae or adults. Whether or not the weir results in populations of these crustaceans being below their potential maximum numbers remains unknown, but this is likely. Palaemon concinnus has not previously been reported from Lake Mzingazi. Given its presence in other coastal lakes in the region, and its occurrence in Mzingazi River but apparent absence in Lake Mzingazi, it is possible that the Mzingazi Weir does act as a barrier to upstream migration.

\section{The potential value of a fishway at Lake Mzingazi}

South African guidelines for evaluating the necessity for fishways to be incorporated into the design of artificial barriers across rivers were formulated almost 20 years ago (DWAF, 1995). Although focussed on ensuring connectivity between river reaches, these guidelines can also be used as a tool to facilitate decisions regarding fishways in coastal lowlands where marine-estuarine-freshwater connectivity is threatened or already lost. Applying the principles to this study indicates 3 main aspects to consider in evaluating the potential benefit of installing a fishway at Lake Mzingazi:

\section{Characteristics of the system}

The Mhlathuze coastal lakes are the southernmost of a set of 12 freshwater lakes on the Zululand Coastal Plain. Of these lakes, Sibaya, Mzingazi and Cubhu probably support the best representative populations of relict estuarine faunas (Reavell and Cyrus, 1989). Mzingazi is the largest of the Mhlathuze lakes and is mainly free of pollution or other impacts. In terms of water quality, habitat and biodiversity, this lake probably has the best conservation value and potential. The significance of this system as secondary nursery habitat for estuarine-associated fishes has been emphasised by Weerts and Cyrus (2001). Its importance for invertebrates (MacKay and Cyrus, 2001) and avifauna (Cyrus, 2001b) has also been highlighted.

The saltwater barrier at the head of Mzingazi Canal potentially obstructs movement of aquatic fauna but this impact has been mitigated by the construction of a bypass sluice that is effective in allowing upstream migration of estuarine and marine-spawning fauna. Some sections of the river exhibit low oxygen concentrations, but these are restricted to mid-channel, bottom waters in deep areas. Fish and crustaceans migrating to freshwater habitats from marine spawning grounds often use shallow, marginal areas (Blaber, 1978). Low oxygen concentrations in deeper waters are therefore unlikely to restrict upstream movements. Thus, aside from the weir at the outlet of Lake Mzingazi, there are no impenetrable barriers to natural upstream migrations.

Lake Mzingazi closely resembles Kosi Bay's Lake Nhlange in several aspects. Waters in Lake Nhlange $(210 \mathrm{~km}$ north of Richards Bay) are typically clear with turbidities lower than 5 NTU and salinities ranging between 0 and 1 (Blaber, 1988). Substrates in both lakes comprise clean sands, and emergent, floating and submerged aquatic vegetation forms are similar. Thus, in terms of both physico-chemistry and structural habitat these two lakes are similar. Unsurprisingly they share a similar set of freshwater fishes. However, an additional set of marine and estuarine species that occur in Lake Nhlange are absent from Lake Mzingazi. This is due to the lack of a free connection from Lake Mzingazi to downstream estuarine and marine systems.

Freshwater is abstracted from Lake Mzingazi for domestic and industrial use. This has the potential to alter natural flow regimes and disrupt migration cues, reducing the value of Lake Mzingazi to species relying on freshwater cues to migrate upstream. However, this has been recognised in an assessment of the lake's ecological water requirements (Mackay and Cyrus, 
2001; Weerts and Cyrus, 2001). Flow can be managed to simulate natural hydrological regimes and maintain minimum lake levels to meet the system's ecological needs in accordance with South Africa's National Water Act (Act No. 36 of 1998).

The success of a fishway in re-establishing a migration corridor for various marine-spawning fish and crustaceans will greatly increase the significance of the Mzingazi system. Marine, estuarine and freshwater linkages are an important determinant of the conservation significance of South African estuaries (Turpie et al., 2002). This is especially true in KwaZulu-Natal where the majority of estuaries are small systems that close periodically, and is even more significant north of the Thukela River where estuaries are isolated by wide stretches of coast.

\section{Characteristics of the biota}

In some cases impediments to migrations may be ecologically beneficial. Such situations might arise, for example, when barriers prevent the spread of undesirable alien species (DWAF, 1995). However, no such species have been reported from the Mzingazi system. Rather, indigenous fishes and crustaceans with life cycles involving migration between fresh- and saline water habitats will benefit from a fishway at Mzingazi Weir. Most notably, estuarine fishes will immigrate into the lake as juveniles to utilise nursery habitats.

South African estuarine fishes are generally more tolerant of low rather than high salinity conditions and the majority of those reported from Mzingazi Canal and River have been noted to occur in freshwater coastal habitats (Whitfield et al., 1981). Osmoregulatory stresses of lowered salinities in Lake Mzingazi could be moderated by the system's water chemistry. Windblown salt sprays influence ionic ratios, reflecting the lake's proximity to the sea (Archibald et al., 1986; Harding, 2000), and contribute to high chloride concentrations. The importance of raised chloride levels in the maintenance of a relict estuarine invertebrate fauna has been noted in Lake Sibaya (Allanson and Van Wyk, 1969; Hart, 1979). This landlocked freshwater lake has also retained an estuarine component in its fish assemblage (Bruton, 1980), despite having lost any free connection with the marine environment since the sea level dropped during the Pleistocene glaciation (Hill, 1969).

Should connectivity between the lower Mzingazi River and the lake be restored the majority of the estuarine and marine fishes in the system would utilise lake habitat as a matter of preference rather than necessity. Most of these fishes can complete their juvenile life stages in the Mzingazi system without access to lake waters. It is therefore unlikely that regional extinctions have resulted from disrupted migration cycles due to the existing weir, or will occur should a fishway not be constructed. However, these species can be regarded as locally extinct from the Mzingazi system above the lake outlet. By limiting nursery area available to their juveniles, the population potentials of these fishes are most probably being restricted. Several are endemic to southern Africa and/or have conservation significance. In the light of continued habitat degradation and fragmentation in the estuaries of KwaZulu-Natal, which are primary nursery areas, the role of coastal lakes in the region as secondary nursery areas is potentially of national importance (Weerts and Cyrus, 2001). Should connectivity be restored, mullet species M. capensis and L. alata will likely recruit into the lake more abundantly than other estuarinedependent marine species. Populations of M. capensis have declined throughout South Africa due to obstructions to migration into river reaches used as nursery areas (Bok, 1979). A similar influence is likely to have reduced numbers of $L$. alata and this species is also considered to be rare and threatened in South Africa (Cyrus, 2001a).

Importantly, increases in euryhaline marine species are unlikely to result in losses of freshwater species in the lake. Freshwater and relict estuarine species presently in the system are mostly omnivores or planktivores and most have a preference for marginal, vegetated habitats. Species likely to benefit the most from a fishway and recruit to the lake in greatest abundance are open water piscivores or benthic and iligophagous feeders. These fishes will therefore fill habitat and trophic niches that are underutilised at present.

Fewer crustacean than fish species are likely to benefit from a fishway at Lake Mzingazi. However, V. litterata and the Macrobrachium prawns have an obligatory need to migrate between marine or estuarine and freshwater habitats. Only a very small section of the lower Mzingazi River can be regarded as completely fresh and juvenile and adult habitat for these crustaceans is limited below the lake. However, unlike the fish species, these crustaceans can and do ascend the weir in its present form and recruit into the lake, even during normal flows. This is probably achieved by crawling up the spillway in the spray zone of water cascading over the weir. This tactic is known to be used by the megalopae of Varuna to overcome much higher weirs than that at Lake Mzingazi (pers. obs), and has also been reported for the postlarvae of freshwater prawns from other parts of the world (Benstead et al., 1999). Nevertheless, recruitment of these crabs and prawns into the lake is almost certainly limited by the weir. These species will use a fishway should a suitable one be provided, and this will enhance recruitment and therefore increase productivity in the lake (and streams feeding into it).

\section{Characteristics of the barrier}

The outflow weir at Lake Mzingazi prevents upstream migration of fish during all normal flow conditions. Only Anguilla spp. (freshwater eels) are likely to be able to ascend the barrier in its present form. While most of the migratory crustacean species utilising the system can negotiate their way over the weir and into the lake, effects on their population numbers are likely. During episodic floods, lake level rises sufficiently for overflow to activate a natural bypass drainage line. This is used by marine-spawned fish species as a migration route into the lake. However, this occurs at such irregular intervals that the lake can be regarded as inaccessible for estuarine and marine spawning fish species.

The low weir height and topography of the lake berm is such that a fishway can easily be incorporated at the outlet. Potential exists to use the route exploited by fish during floods to reinstate connectivity of the lake with downstream waters. This has engineering benefits in terms of costs and is likely to have biological benefits as well. A conceptual design has been developed and the feasibility of incorporating such a 'naturaltype' fishway confirmed (Bok, 1998). This design will offer a cost-effective method of reinstating a migration route that was lost over 70 years ago.

\section{CONCLUSIONS}

The conservation status and potential of Lake Mzingazi justifies the installation of a fishway at the outlet weir, given the fact that this weir constitutes the only obstacle to movement 
of important migratory fish and crustacean species. Although these species can complete their life cycles under existing conditions, restoring marine-estuarine-freshwater connectivity presents a considerable opportunity to increase their populations regionally. It is likely that some ecosystem changes will take place in the lake should a fishway be installed. For example, the introduction of predatory fish species may reduce populations of smaller fish such as G. aestuaria. These losses will probably be compensated by higher recruitment of juvenile mullet and it is unlikely that piscivorous birds will suffer from increased competition for prey items. Increased predation on crustaceans is also likely to be offset by increased recruitment of these species into lake waters.

Characteristics of the weir favour the installation of a fishway. Cost implications could be kept to a minimum, as a natural-type fishway will avoid the need for specialised structures. The low drop over the weir precludes the need to design a fishway to allow for return migrations of larger fishes, as long as the tail-water pool is cleared of boulders to avoid undue injury to animals returning downstream. The design of the fishway will be critical to its success. Classical fishway designs used in temperate rivers are unlikely to be successful. Target fauna here are juvenile rather than adult fishes and salmonid-type fishways have frequently been shown to be unsuitable for nonsalmonid species (Stuart and Mallen-Cooper, 1999). A fishway suitable for juvenile fishes is, however, likely to meet the needs of migrating invertebrate species, so special design criteria for crustaceans are unlikely to be necessary.

The need for fishways at other coastal lakes within the jurisdiction of the uMhlathuze Municipality has previously been raised. Lake Cubhu, $15 \mathrm{~km}$ south of Mzingazi, is also an important nursery for estuarine-dependent marine fishes that cannot fulfil their population potentials due to the modified nature of that lake's outlet (Weerts and Cyrus, 2001). However, given the larger size of Lake Mzingazi it seems prudent to prioritise the construction of a fishway at this system. Re-establishing marine-estuarine-freshwater connectivity here will reinstate a natural migration route that has been impeded for over 70 years and will partially restore the system to its original state.

\section{POSTSCRIPT}

This work was originally submitted as a report to the uMhlathuze Municipality at their request to investigate the need and potential for a fishway to be installed at Lake Mzingazi as part of safety upgrades needed to the weir. It was favourably received and a fishway was subsequently incorporated into the design of the upgraded embankment. It was designed by Dr Peter Wessels of the Department of Water Affairs with specialist input from Dr Anton Bok. Construction of the new structure was completed in 2006 (Botha et al., 2006). The design specifically sought to create hydraulic conditions suitable for the migration of small (young), weakly-swimming fish and climbing species (eels, crabs and prawns). Monitoring of the fishway has commenced and is currently the focus of post-graduate research at the University of Zululand.

\section{REFERENCES}

ALLANSON BR and VAN WYK JD (1969) An introduction to the physics and chemistry of some lakes in northern Zululand. Trans. R. Soc. S. Afr. 38 217-240.

ASHELBY CW, PAGE TJ, DE GRAVE S, HUGHES JM and JOHNSON ML (2012) Regional scale speciation reveals multiple invasions of freshwater in Palaemoninae (Decapoda). Zool. Scripta 41 293-306.
ARCHIBALD CGM, FOWLES BK, MULLER MS and WARWICK RJ (1986) Water Quality and Limnological Characteristics: Lake Mzingazi. In: Walmsley RD and Grobler JH (eds.) An Evaluation of the Impact of Urban and Recreational Development on the Ecology and Usage of Lake Mzingazi. Occasional Report Series No. 6. Ecosystems Programmes FRD CSIR Pretoria. 60 pp.

BARNARD KH (1950) Descriptive catalogue of South African Decapod Crustacea (Crabs and shrimps). Ann. S. Afr. Mus. 38 $1-837$.

BENSTEAD JP, MARCH JG, PRINGLE CM and SCATENA FN (1999) Effects of a low-head dam and water abstraction on migration of tropical stream biota. Ecol. Appl. 9 656-668.

BOEHLERT GW and MUNDY BC (1988) Roles of behavioral and physical factors in larval and juvenile fish recruitment to estuarine nursery areas. In: Weinstein MP (ed.). Larval Fish and Shellfish Transport through Inlets. Am. Fish. Soc. Symp. 3 51-67.

BOK AH (1979) The distribution and ecology of two mullet species in some fresh water rivers in the eastern Cape, South Africa. J. Limnol. Soc. S. Afr. 5 97-102.

BOK AH (1998) Conceptual design of a natural-type fishway for Lake Mzingazi. Anton Bok and Associates Report. 12 pp.

BOTHA D, BADENHORST D and MULLER I (2006) Fishway, first of its kind in South Africa. I-civil engineering. S. Afr. Inst. Civ. Eng. 14 4-5.

BLABER SJM (1978) Fishes of the Kosi system. Lammergeyer 24 $28-41$.

BLABER SJM (1988) Fish communities of south east African coastal lakes. Peuplements ichtyologiques des lagunes du sud est de l'Afrique. Biologie et écologie des poissons d'eau douce Africains 216 351-362.

BRUTON MN (1980) An outline of the ecology of Lake Sibaya, with emphasis on the vertebrate communities. In: Bruton MN and Cooper KH (eds.) Studies of the Ecology of Maputaland. Rhodes University and the Natal Branch of the Wildlife Society of Southern Africa, Grahamstown. 382-407.

BRUTON MN and APPLETON CC (1975) Survey of Mgobezeleni lake-system in Zululand, with a note on the effect of a bridge on the mangrove swamp. Trans. R. Soc. S. Afr. 41 283-295.

COETZEE DJ (1988) Collections of freshwater shrimps along the southern coast of South Africa. S. Afr. J. Zool. 23 59-63.

CONNELL AD and ROBERTSON W (1986) Recent records of mega lopae of the crab Varuna litterata (Fabr.) entering Natal estuaries. S. Afr. J. Zool. 21 184-185.

CORT MC and SCHOONBEE HJ (1993) Investigation into the salinity preferences of successive larval development forms of five indigenous species of the freshwater prawn Macrobrachium. Water SA 19 153-162.

COKE M (1988) Freshwater fish conservation in South Africa: a rising tide. J. Limnol. Soc. S. Afr. $1429-34$.

CYRUS DP (2001a) A preliminary assessment of the impacts on estuarine associated fauna from an intra-basin transfer and fresh water abstraction from aquatic systems in the Richards Bay area of KwaZulu-Natal, South Africa. Afr. J. Aquat. Sci. 26 115-120.

CYRUS DP (2001b) Aquatic avifauna of the coastal lakes of the Mhlathuze River system. Afr. J. Aquat. Sci. 26 77-83.

CYRUS DP, MARTIN TJ and REAVELL PE (1997) Salt-water intrusion from the Mzingazi River and its effects on adjacent swamp forest at Richards Bay, Zululand, South Africa. Water SA 23 101-108.

DAVIES B and DAY J (1998) Vanishing Waters. University of Cape Town Press, Cape Town. 487 pp.

DE GRAVE S, CAI Y and ANKER A (2008) Global diversity of shrimps (Crustacea: Decapoda: Caridea) in freshwater. Hydrobiologia 595 287-293.

DE VILLIERS CJ, HODGSON AT and FORBES AT (1999) Studies on estuarine macroinvertebrates. In: Allanson BR and Baird D (eds.) Estuaries of South Africa. Cambridge University Press, Cambridge. 167-208.

DWAF (DEPARTMENT OF WATER AFFAIRS AND FORESTRY, SOUTH AFRICA) (1991) Fishways in South Africa. Proceedings of a workshop on the rationale and procedures for the evaluation of the necessity for fishways in South African rivers. Department of Water Affairs, Pretoria. 
DWAF (DEPARTMENT OF WATER AFFAIRS AND FORESTRY, SOUTH AFRICA) (1995) Fishway criteria workshop. Proceedings of a workshop to evaluate fishway monitoring results and to formulate guidelines for determining the necessity and design for fishways in southern Africa. Department of Water Affairs and Forestry, Pretoria.

FOWLES BK and ARCHIBALD CGM (1987) Zooplankton and estuarine relict (benthic) fauna in Lake Mzingazi, a freshwater coastal lake in Natal. J. Limnol. Soc. S. Afr. 13 66-74.

HARDING WR (1992) Zeekoevlei-water chemistry and phytoplankton periodicity. Water SA 18 237-237.

HARDING WR (2000) Mhlathuze lakes - Lake water requirements. Limnological considerations. In: Kemper NP (ed.) Mhlathuze system ecological reserve (quantity) study. Report on lake level requirements. Supporting Report No. 2. Department of Water Affairs and Forestry Report No. W120-00-1399. Department of Water Affairs and Forestry, Pretoria.

HART RC (1979) The invertebrate communities: zooplankton, zoobenthos and littoral fauna. In: Allanson BR (ed.) Lake Sibaya. Monogr. Biol. 36 108-161.

HART RC and BOANE C (2004) Limnology of southern African coastal lakes - new vistas from Mozambique. Afr. J. Aquat. Sci. 29 $145-159$.

HILL BJ (1969) The bathymetry and possible origin of Lakes Sibayi, Nhlange and Sifungwe in Zululand (Natal). Trans. R. Soc. S. Afr. 38 205-216

HUGHES DA (1966) Investigations of the 'nursery areas' and habitat preferences of juvenile Penaeid prawns in Mozambique. J. Appl. Ecol. 3 349-354.

IUCN (2012) IUCN Red List of Threatened Species. Version 2012.2. URL: http://www.iucnredlist.org (Accessed 22 March 2013).

JAMES NC, COWLEY PD, WHITFIELD AK and KAISER H (2008) Choice chamber experiments to test the attraction of postflexion Rhabdosargus holubi larvae to water of estuarine and riverine origin. Estuar. Coast. Shelf Sci. 77 143-149.

JUBB RA (1967) The Freshwater Fishes of Southern Africa. Balkema, Cape Town. 248 pp.

KELBE BE and GERMISHYUSE T (2000) Hydrology of coastal lakes at Richards Bay. In: Kemper NP (ed.) Mhlathuze system ecological reserve (quantity) study. Report on lake level requirements. Supporting Report No. 2. Department of Water Affairs and Forestry Report No. W120-00-1399. Department of Water Affairs and Forestry, Pretoria.

MACKAY CF and CYRUS DP (2001) Available information on macroinvertebrates of the Mhlathuze coastal lakes: setting the ecological reserve (lake water requirements). Afr. J. Aquat. Sci. 26 85-98.

MACKAY CF, WEERTS SP, BUTHELEZI PP and CYRUS DP (2001) Biological monitoring of the effects of sewage effluent in the Mzingazi Canal. CRUZ Investigational Report No. 93. 85 pp.

MILLENNIUM ECOSYSTEM ASSESSMENT (2005) Ecosystems and Human Well-Being: Synthesis. Island Press, Washington, DC.
PENHA-LOPES G, TORRES P, CANNICCI S, NARCISO L and PAULA J (2011) Monitoring anthropogenic sewage pollution on mangrove creeks in southern Mozambique: A test of Palaemon concinnus Dana, 1852 (Palaemonidae) as a biological indicator. Environ. Pollut. 159 636-645.

REAVELL PE and CYRUS DP (1989) Preliminary observations on the macrocrustacea of coastal lakes in the vicinity on Richards Bay, Zululand, South Africa. S. Afr. J. Aquat. Sci. 15 103-128.

RYAN PA and CHOY SC (1990) Observations on the mass upstream migration of Varuna litterata (Fabricius) megalopae (Decapoda, Brachyura, Grapsidae) in Fiji. Crustaceana 58 237-249.

SERFONTEIN N (2000) Historical and present operation of lakes. In: Kemper NP (ed.) Mhlathuze system ecological reserve (quantity) study. Report on lake level requirements. Supporting Report No. 2. Department of Water Affairs and Forestry Report No. W120-001399. Department of Water Affairs and Forestry, Pretoria.

SHORT JW (2004) A revision of Australian river prawns, Macrobrachium (Crustacea: Decapoda: Palaemonidae). Hydrobiologia 525 1-100.

SKELTON PH (2000) Flagships and fragments - perspectives on the conservation of freshwater fishes in southern Africa. Afr. J. Aquat. Sci. 25 37-42.

STUART IG and MALLEN-COOPER M (1999) An assessment of the effectiveness of a vertical-slot fishway for non-salmonid fish at a tidal barrier on a large tropical/subtropical river. Regul. River: Res. Manage. 15 575-590.

SUBRAMANIAN P, SAMBASIVAM S and KRISHNAMURTY K (1980) Experimental study on the salinity tolerance of Macrobrachium idae larvae. Mar. Ecol. Prog. Ser. 3 71-73.

TURPIE JK, ADAMS JB, JOUBERT A, HARRISON TD, COLLOTY BM, MAREE RC, WHITFIELD AK and WOOLDRIDGE TH (2002) Assessment of the conservation status of South African estuaries for use in management and water allocation. Water $S A$ 28 191-206.

WASSERMAN RJ, WEYL OLF and STRYDOM NA (2011) The effects of instream barriers on the distribution of migratory marinespawned fishes in the lower reaches of the Sundays River, South Africa. Water SA 37 495-504.

WEERTS SP and CYRUS DP (2001) The ichthyofauna of the Mhlathuze coastal lakes: some preliminary results. Afr. J. Aquat. Sci. 26 99-107.

WEERTS SP and CYRUS DP (2002) Occurrence of young and smallsized fishes in different habitats within a subtropical South African estuary and adjacent harbour. Mar. Freshwater Res. 53 447-456.

WEERTS SP, CILLIERS G and CYRUS DP (2003) Estuarine macrocrustacea of Richards Bay Harbour, South Africa, with particular reference to the Penaeid prawns. Afr. J. Zool. 38 286-296.

WHITFIELD AK (1998) Biology and ecology of fishes in southern African estuaries. Ichthyological Monogr. JLB Smith Inst. Ichthyology 2 1-223.

WHITFIELD AK, BLABER SJM and CYRUS DP (1981) Salinity ranges of some southern African fish species occurring in estuaries. S. Afr. J. Zool. 16 151-155. 